\title{
Opinions evolve on Kauffman patent
}

In April, Applied Molecular Evolution (AME; San Diego, CA), a small, private biotechnology company currently developing novel protein therapeutics, is expected to unveil the terms of its much-anticipated licensing program for patent rights the company holds on directed evolution - a family of techniques that are used to isolate useful DNA, RNA, or protein sequences from pools of randomized or mutagenized sequences. Although AME insists it will be generous and nonconfrontational in enforcing its sweeping rights, companies in the field and patent experts who have followed the issue closely unsurprisingly contend that the scope of the Kauffman patentnamed after Stuart Kauffman and Marc Ballivet, the inventors of this directed evolution approach-is considerably smaller than AME claims.

Many companies now use techniques that could be described as directed evolution, usually with the aim of improving the activity or specificity of specific proteins. A few have specialized in applying this type of technology to protein engineering, and these include Diversa (San Diego, CA) and Maxygen (Redwood City, CA), both of which are actively pursuing directed evolution for industrial and therapeutic applications. Other companies, like Dyax (Cambridge, MA), Cambridge Antibody Technology (Cambridgeshire, UK), and MorphoSys (Munich, Germany), use randomized or mutagenized pools of sequences in phage libraries and antibody screening.

The anticipation of AME's licensing program has centered on the apparently broad claims of the Kauffman patent (US 5,723,323), issued to the company in 1998 and which some observers suggest would cover virtually any use of randomized DNA sequences to generate protein diversity (Nat. Biotechnol. 16, $411,1998)$. If the broad interpretation of the Kauffman patent prevails, all these companies_-not to mention many of their partners and virtually every big pharmaceutical company-would need to obtain licenses from AME to continue existing projects. "There's so much value to this [patent] that no one company could practically use the technology in all the areas covered by the patent," claims Bill Huse, CEO of AME. Indeed, under the broader interpretation, it is possible that only companies like Ribozyme, whose technology relies primarily on RNA engineering, would be able to avoid a licensing requirement."

AME, formerly known as Ixsys, has stated that licenses to use the technology will be granted on a nonexclusive basis under "reasonable" terms. Huse explains that AME plans to model its licensing program on the comment. (Diversa, which went public on February 14, was still in its legally mandated "quiet period" and was therefore unable to communicate with reporters.)

Pamela Hay, senior vice president of corporate development at Dyax, a company developing phage display technology and the only one
willing to comment on willing to comment on
record, says that "our view at this moment is that we do not require a license [for the Kauffman patent], because we do not do stochastic or randomly generated libraries as described in the patent." A representative of another directed evolution company, who requested anonymity, concurred with the Dyax position, adding that the patent's specific coverage hinges in part on the meaning of the word "stochastic," which

Optimal Protein

is not well defined in patent law.

one employed by Stanford University for the Cohen-Boyer recombinant DNA patent. In that case, a patent that covered most types of recombinant DNA work was licensed under terms that required only a small up-front payment and a modest royalty - an arrangement that was widely praised by biotechnology companies as fair and reasonable. "We don't aspire to be the Microsoft of directed evolution," says Larry Bloch, AME's vice president of business development.

Kenneth Chahine, patent counsel at gene therapy company Avigen, predicts that basic business arithmetic will play a role in corporate responses to AME's licensing program: "The amount of litigation will be inversely proportional to the license terms - the more reasonable the terms, the less litigation." If the AME program does parallel Stanford's licensing of the Cohen-Boyer patent, Chahine's prediction seems reasonable, as some observers suggest that companies often bought a license for the recombinant DNA patent simply because the licensing fee was cheaper than the litigation expenses would have been.

Meanwhile, AME's claims about reseaonable licensing terms should reassure companies working with directed evolution techniques, yet it is very difficult to find a company that admits it will need to license the Kauffman patent: Most companies contacted for this article avoided comment or gave guarded responses, at least one citing concern that the issue could be headed for court. Cambridge Antibody Technology did not return phone calls and emails requesting comments, while MorphoSys declined to
Not only does dispute over the scope of AME's rights persist nearly two years after the patent was granted, but some experts argue that the "wrapper," or collection of legal arguments brought out during the prosecution of the Kauffman patent, may seriously reduce its breadth. One patent attorney, who asked not to be named, explained that the patent appears to be specific for completely random DNA mutagenesis, thus exempting any technique that mutagenizes or randomizes a specific target DNA sequence. The distinction could have significant implications because many directed evolution projects, like the antibody engineering approaches being used by Cambridge Antibody Technology and the industrial enzyme optimization being pursued by Diversa, tend to focus on redesigning specific protein domains.

AME's Bloch is not surprised at the differing interpretations, explaining that "it's a complicated area and I think there can be misunderstandings," asserting that AME's broad interpretation will prevail "after [each company's] patent counsel has sufficient time to review the material."

Nevertheless, disputes over interpretations and legal context suggest that AME's patent series and efforts to license it may ultimately be headed for litigation. However, Bloch hopes the new licensing program, once unveiled, will ease some of the tension: "Once people have the opportunity to fully review the documentation, our faith is that people are going to be ethical and license things that they are using."

Alan Dove 